\section{An international study of the factors explaining high-growth expectation in new ventures: a gender perspective}

\author{
Matilde Ruiz Arroyo \\ University of Granada, Department of Business Administration, \\ Melilla, Spain \\ María del Mar Fuentes Fuentes \\ University of Granada, Department of Business Administration, \\ Granada, Spain \\ Jenny María Ruiz Jiménez \\ University of Granada, Department of Business Administration, \\ Granada, Spain
}

Received on

02/04/2014

Approved on 06/09/2016

Responsible editor:

Prof. Dr. João Maurício Gama

Boaventura

Evaluation process:

Double Blind Review

\begin{abstract}
Purpose - Given the importance of high-impact entrepreneurship to economic growth, and the remarkable potential that women entrepreneurs have yet to contribute to the economic activity, in this study we propose a model to explain an entrepreneur's high-growth expectation based on relevant strategic variables, additionally addressing the identification of possible gender differences in the predictors of an entrepreneur's expectation for high-growth.
\end{abstract}

Design/methodology/approach - We use data from the 2009 Global Entrepreneurship Monitor (GEM), working on a sample of 8,641 earlystage entrepreneurs referred to 49 countries. We perform hierarchical binomial logistic regressions, including a segmented analysis to compare the model between women and men entrepreneurs.

Findings - Based on our results, we confirm gender as a strong explanatory variable for growth aspirations, with women having lower levels of expectation for the high-growth of their ventures. Moreover, in comparing the determinants of high-growth expectation by gender, we can conclude that the set of significant predictors is not the same for male and female entrepreneurs. These results suggest a moderating effect of gender in shaping the configuration of the factors determining an entrepreneur's propensity for high-growth.

Originality/value - This research contributes to a better understanding of the factors driving high-growth expectation, thus helping to advance knowledge in the area of strategic entrepreneurship, as well as in women's entrepreneurship literature. As for practical implications, our results point out to the necessity of designing specific policies for men and women, in order to promote high-growth entrepreneurship.

Keywords - Firm high-growth expectation; gender; resource-based view; organizational factors.

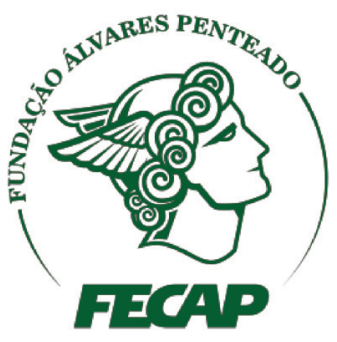

Review of Business Management

DOI: $10.7819 /$ rbgn.v18i60.1947 


\section{Introduction}

Given the important contribution of firm growth to socio-economic development, especially through job creation and tax revenue (Douglas, 2013; Lichtenstein, 2000), interest in firm growth and its determinants arises both from the policy and the academic spheres. Although firm growth has been studied from different perspectives and disciplines - namely, economics, industrial organization, and entrepreneurship (Stam, 2010)_, a fuller development has occurred in recent years in entrepreneurship (Davidsson, Achtenhagen, \& Naldi, 2006), particularly as part of the stream of research devoted to the study of strategy and entrepreneurship (Montiel Campos, Solé Parellada, \& Palma, 2012). Specifically, highgrowth entrepreneurship emerges as a crucial phenomenon due to its remarkably positive impact on job creation, sustainable economic growth, and ultimately on economic development (Capelleras, Contín-Pilart, Larraza-Kintana, \& Martin-Sanchez, 2016). Within this research stream, the founder's aspirations and expectations have been proven to be chief contributors to firm growth (e.g., Baum \& Locke, 2004; Cassar, 2006; Davidsson, 1989; Delmar \& Wiklund, 2008; Wiklund \& Shepherd, 2003). Given that every high-impact firm begins as a startup (Davis \& Shaver, 2012), the study of highgrowth expectations in new ventures is relevant to understanding the phenomenon of high-growth entrepreneurship.

As economic growth potential in most industrialized countries is gendered (Arenius \& Kovalainen, 2006), the analysis of high-growth entrepreneurship from a gender perspective is necessary and relevant, as more women entrepreneurs pursuing growth will contribute more to job creation and economic development. Prior literature suggests that women's firms tend not only to be smaller than men's, but also to grow more slowly. Some scholars argue that women face constraints in the availability of resources such as human capital or financial access, which condition their firm's size and their options to grow (Brush, Carter, Gatewood, Green, \& Hart, 2004). Other studies indicate, however, that differences in growth may also come from different growth intentions. Research on women's growth attitudes suggests that many women deliberately choose not to grow their firms, but rather to keep them small (Geoffee \& Scase, 1983), showing conservative growth expectations (Chaganti, 1986; Cliff, 1998) and lower compared to men (Rosa, Carter, \& Hamilton, 1996). We thus can expect gender to play a role in the determination of high-growth expectations. Several years ago, Starr and Yudkin (1996) claimed for the need of more studies to help define preconditions for growth in women-owned businesses, and more recently, Morris, Miyasaki, Watters and Coombes (2006) stress insufficient attention to understanding the growth aspirations of women entrepreneurs given their underrepresentation in the proportion of high-growth firms. Similarly, Davis and Shaver (2012) indicate that women's participation in high-growth firms constitutes a recent and necessary research demand. However, to our best knowledge, research on high-growth expectation entrepreneurship from a gender perspective is scarce (e.g., Davis \& Shaver, 2012; Estrin \& Mickievicz, 2011).

In another vein, our research focuses on new ventures, given their distinctive features related to growth (Gilbert, McDougall, \& Audretsch, 2006) and their aspirations for growth (Schøtt \& Bager, 2004). Whereas growth of established firms focuses on maintaining the viability achieved, new venture growth is about obtaining that viability, as new ventures suffer from liability of newness (Gilbert et al., 2006). On the other hand, we focus on SMEs, due to their high representation among national business populations (European Commission, 2014; United States International Trade Commission [USITC], 2010). SMEs' growth is thus of significant importance to the economy, particularly in solving unemployment and economic recession by creating new jobs (Reynolds, Bygrave, \& Autio, 2003; Tominc \& 
Rebernik, 2007), and by generating innovation and technological change (Pagano \& Shivardi, 2003).

The present study attempts to develop a deeper understanding of the factors that determine high-growth expectation in new ventures, regarding the issue of the entrepreneur's gender in a double view. First, on the basis of a model integrating strategic factors related to firm's resources and capabilities arising from a review of the relevant literature, we evaluate the role of gender in an entrepreneur's high growth expectation, by assessing its direct effect. Second, we test whether the relevant variables may vary by gender. Therefore, our research questions are: Which strategic organizational factors can determine the high-growth expectation of an entrepreneur? What is the role of gender in an entrepreneur's high-growth expectation? Finally, comparing male and female analyses, which are the relevant factors in explaining male and female entrepreneurs' high-growth expectation? Moreover, may the configuration of the predictors vary by gender?

The rest of the document is organized as follows. In Section 2 we present our theoretical framework and hypotheses. Section 3 describes the research design. Section 4 presents the results, and the final section discusses the findings and presents the main conclusions and practical implications, as well as limitations and directions for future research.

\section{Literature review and hypotheses}

The strong relationship between realized firm growth and growth intentions (e.g., Baum \& Locke, 2004; Davidsson, 1989; Delmar \& Wiklund, 2008) allows us to translate arguments from firm growth literature into explanations of growth expectations. Regarding firm growth literature, the effect of the firm's resources and capabilities has been widely studied (Dutta \& Thornhill, 2008). The resource-based view (RBV) states that organizational performance is significantly determined by the organization's resources and capabilities (Kazanjian \& Rao, 1999). A form of organizational performance is firm growth (Davidsson et al., 2006a), so it has been said that a firm's unique portfolio of tangible and intangible resources and capabilities influences the rate and direction of its growth (Barney, 1991; Penrose, 1959). We therefore use $\mathrm{RBV}$ as the appropriate theoretical framework to justify and present our study hypotheses, finally leading to our proposed model of high-growth expectation. Indeed, it is reasonable to think that the way in which the entrepreneurs perceives their firm's resources and capabilities will have an influence on the future growth expectation for the business. After a literature review on firm growth and growth intentions, we identify a group of strategic organizational factors related to firm growth and aspirations for growth, and hypothesize their relationship with high-growth expectation.

Besides this, most previous literature on growth intentions and aspirations supports the idea that women entrepreneurs have lower growth expectations for their firms than their male counterparts (e.g., Cliff, 1998; Davis \& Shaver, 2012; Mitra, 2002). Based on the arguments found in the literature on women's growth aspirations, we can expect gender to play a role in the formation of an entrepreneur's expectation for high growth. Therefore, and besides the strategic firm-related factors, we include a gender variable in our model and firstly present a hypothesis regarding the effect of gender on high-growth expectation.

\section{I Gender and high-growth expectation}

Some authors have suggested that women have conservative growth expectations (Chaganti, 1986; Cliff, 1998) and deliberately choose not to grow their firms, instead maintaining a small and manageable size (Geoffee \& Scase, 1983). In more recent studies, we find the descriptive results of Autio and Acs (2007) suggesting that high-growth expectation may significantly depend 
on gender, with women entrepreneurs generally pointing at lower growth ambitions than men. Relatedly, Morris et al. (2006) find that women business owners seem to be less motivated to grow their businesses than their male counterparts, and Rosa et al. (1996) conclude that women show lower growth expectations compared to men. Supporting these ideas we find the results of Cowling and Taylor (2001), showing that selfemployed men are three times more likely than self-employed women to develop a business with employees. Following Cassar (2006), women present lower estimates of future revenues than men, which can implicitly derive into lower growth expectations if we consider growth as organic, like it occurs in most SMEs. More recently, Davis and Shaver (2012) find that women are less likely than men to express high-growth intentions, and the study by Estrin and Mickievicz (2011) shows that men are more likely than women to engage in high-aspiration entrepreneurial activity under certain institutional conditions. Similarly, Manolova, Brush, Edelman and Shaver (2012) find significant gender differences in the growth intentions of new venture founders, as well as different motives and desired outcomes.

These results support the idea of women entrepreneurs having lower high-growth expectations than their male counterparts. The literature is somewhat inconclusive, however, as other studies find no gender differences in aspirations and preferences for growth (Kolvereid, 1992; Menzies, Diochon, \& Gasse, 2004). We thus propose:

H1: Women entrepreneurs are less likely than men entrepreneurs to have high-growth expectation for their firm.

\subsection{Organizational factors and high- growth expectation}

As explained above, in proposing a model to explain high-growth expectation, we build on insights from the RBV (Alvarez \& Busenitz,
2001; Barney, 1991), by carrying out a review of the relevant literature on firm growth and growth intentions, to identify strategic organizational resources and capabilities.

On the other hand, there is prior evidence suggesting gender differences in the factors affecting growth intentions (Manolova, Carter, Manev, \& Gyoshev, 2007; Manolova et al., 2012), therefore we formulate each hypothesis for men and women, in order to further test each hypothesis separately by gender (the statistical justification and procedure of this segmentation approach will be explained in the methodology section).

Regarding strategic organizational factors related to growth expectation, first we find the ownership form as a critical factor for the direction and operation of a venture (O'Regan, Ghobadian, \& Gallear, 2006). Specifically, team management can be a source of resources and capabilities fostering firm growth. Team members managing a firm constitute a valuable resource (Barney, 1991), having a crucial role in organizational performance (Barringer, Jones, \& Neubaum, 2005). The combination of attributes and abilities of team members may lead to a higher growth (Hambrick \& Mason, 1984). Management teams imply diversity of abilities, knowledge, views, experience, cognitions, etc., therefore a variety of members enables individuals to compensate for each other's competence deficits (Cooper, Gimeno-Gascon, \& Woo, 1994), with potential positive effects on firm performance and growth. For example, Miller and Triana (2009) suggest that different forms of diversity in top management teams provides the firm with varied human and social capital, leading to the generation of new ideas or to improved resources allocation, which in turn can derive into higher firm growth. On the other hand, prior research consistently assert that larger teams have access to more resources (Kozlowski \& Bell, 2003), which leads to a greater resource base to build on future growth.

Previous evidence on firm growth literature support the ideas above, like the study by Gundry 
and Welsch (2001), which finds that high-growthoriented entrepreneurs are nearly twice as likely to use team-based forms of organization for their firms. Similarly, Davidsson et al. (2006a) conclude that team size in terms of number of owners/ founders has a positive effect on firm growth. Particularly for growth aspirations, Morris et al. (2006) indicate that the presence of equity partners (that is, the existence of more than one owner) is important in explaining the desire for the growth of the business.

Taking the aforementioned into account, we propose that:

H2: High-growth expectation is more likely among men entrepreneurs (2a) / women entrepreneurs (2b) whose firm is run by an entrepreneurial team than among sole entrepreneurs.

The RBV acknowledges internationalization as a way to accumulate organizational resources and capabilities (Hessels \& Stel, 2011). Internationalization can thus be seen as a source of competitive advantage through which firms can get higher performance and better bases for future growth, based on the access to more resources (Autio \& Acs, 2007; Oviatt \& McDougall, 1994). Specifically, Lu and Beamish (2001) suggest that export activities can lead to an increase in a firm's knowledge base and human capital stock. Through internationalization, the firm is also exposed to more available opportunities (Oviatt \& McDougall, 1994), as well as it grows its experience and organizational learning (Autio, Sapienza \& Almeida, 2000), developing new capabilities, routines and practices (Zheng \& Khavul, 2005).

Studies like those of Coad and Tamvada (2012) confirm these ideas, as they find that the export activity has a positive effect on different measures of firm growth. In a similar vein, other research proves that growth-oriented entrepreneurs are more likely to pursue a higher presence of their firms in international markets
(De Clercq, 2005; Heinonen, Pukkinen, \& Nummela, 2004). Specifically for growth aspirations, internationalization may lead to expectations of business expansion and job creation (Autio \& Sapienza, 2000), i.e., growth expectation, based on higher possibilities of accessing new markets (Gabrielsson, Kirpalani, Dimitratos, Solberg, \& Zucchella, 2008). More recently, Castaño, Méndez and Galindo (2016) prove a positive relationship between internationalization of business activity and expectation of business growth.

Based on the above arguments, we propose that:

H3: High-growth expectation is more likely among men entrepreneurs (3a) / women entrepreneurs (3b) whose firm shows an international orientation than among entrepreneurs managing a firm with no international orientation.

Innovation is widely recognized as a driver of firm growth (O'Regan et al., 2006), as contributor to the creation of competitive advantages and to the improvement of performance (McEvily, Eisenhardt, \& Prescott, 2004). A firm's innovative orientation can have a positive impact on organizational growth (Wiklund, Patzelt, \& Shepherd, 2009), and innovations are positively related to revenue growth (Freel \& Robson, 2004; Thornhill, 2006).

Previous research suggests a positive effect of innovation on growth expectation (Stenholm, 2011), since innovation generates opportunities for growth (Cho \& Pucik, 2005) and provides advantages for reaching new markets and customers (Kleinschmidt \& Cooper, 1991). Related to this, Gundry and Welsch (2011) find that growth-oriented entrepreneurs emphasize innovative activity more than nongrowth-oriented entrepreneurs. In a recent study, Castaño et al. (2016) find an indirect positive effect of innovation on growth expectation for entrepreneurs in the service sector. 
Conceptualizing innovation in the Bruton and Rubanik's view (2002), thus focusing on the entrepreneur's perception of innovation, we propose:

H4: High-growth expectation is more likely among men entrepreneurs (4a) I women entrepreneurs (4b) whose firm has high/medium innovative capability than among those managing a firm with low/no innovative capability.

The application of new technology may influence employment growth positively, especially in the case of young businesses (Terjesen $\&$ Szerb, 2008). Following Autio and Sapienza (2000), young innovative companies that employ cutting edge technologies can get higher levels of firm growth, and Gilbert et al. (2006) conclude that the use of advanced technologies significantly contributes to new venture growth. Along these lines, the results of Barbero, Casillas and Feldman (2011) suggest that organizational capabilities such as the use of technologies in the firm's operations improve efficiency and contribute to growth. Specifically as for growth expectation, Gundry and Welsch (2001) demonstrate that high-growth-oriented entrepreneurs are more likely to pursue technological change, that is, to computerize operations and acquire new equipment. The use of technological resources, understood as new and very new technologies, can influence the future high-growth expectation of the entrepreneur.

We thus propose:

H5: High-growth expectation is more likely among men entrepreneurs (5a) / women entrepreneurs (5b) whose firm employs technological resources than among entrepreneurs managing a firm with no technological resources.

The relationships proposed in the hypotheses above are shown in our theoretical model (Figure 1).

\section{GENDER}

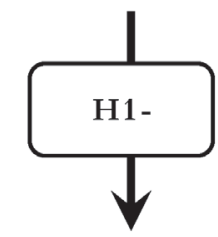

HIGH-GROWT H

EXPECTATION

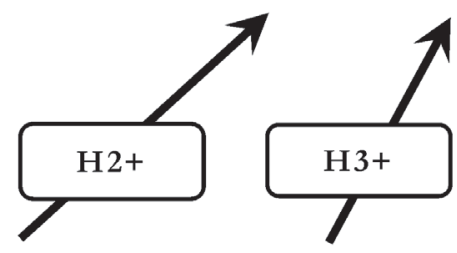

Entrepreneurial team
International orientation

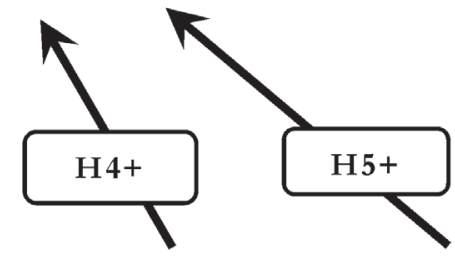

Innovation
New technologies

Figure 1. Theoretical model for entrepreneurs' high-growth expectation 


\section{Data and method}

\section{I Sample}

The empirical study is based on individual-level survey data from the 2009 Global Entrepreneurship Monitor (GEM). On an annual basis, GEM carries out random interviews of at least 2,000 individuals (18-64 years) in each participating country, collecting data on attitudes towards entrepreneurship, entrepreneurial activities and their characterization, in addition to complete socio-demographic data (APS, Adult Population Survey). The process is strictly harmonized and closely supervised across all the participating countries (Reynolds et al., 2005). ${ }^{1}$ Through a battery of up to four filter questions in the survey, GEM is able to identify entrepreneurs and established business owners among the adult population surveyed. Applying a temporal criterion for firm age (42 months old), GEM identifies two main types of entrepreneurs: new or early-stage entrepreneurs (owner-managers of entrepreneurial firms with less than 42 months), and established business owners (owner-managers of firms in existence for more than 42 months) (Reynolds et al., 2005). Given that much of the previous entrepreneurship research focused either only on self-employment or on small businesses after legal registration (Estrin \& Mickiewicz, 2011), thanks to the GEM approach we are able to use data on the whole spectrum of entrepreneurs, not conditioning the sample to registered enterprises only. Additionally, this approach based on uniform definitions may be particularly useful for international samples, as the requirements to legally constitute an enterprise can greatly vary from one country to another, as well as the proportion of legally registered firms. ${ }^{2}$

We focus on new ventures, therefore we select from the total sample those cases classified as owner-managers of nascent and baby businesses, obtaining an initial sample of 13,732 usable observations. However, it was necessary to refine the sample in two steps. First, to avoid the overrepresentation of some countries given their regional GEM structure (for example, the US or
Spain), we applied a random sampling process to ensure a more homogeneous representation of the 49 countries. Second, as explained in the introduction section, we are interested in SMEs, therefore we disregarded observations that referred to large firms. After selection and refinement, we obtain a final sample of 8,641 entrepreneurs managing new ventures from 49 countries, representing all the world regions. The nations included can be seen in Table 1 , with an indication of their stage of development (factordriven, efficiency-driven, innovation-driven, and intermediate transition stages), following the classification made by the Global Competitiveness Report 2009-2010 (Schwab, 2009).

\section{$3 \cdot 2$ Variables}

The variables included in our work consist of dichotomous, categorical, and continuous variables (labels, description and values are shown in Table 2). In addition to our hypothesized variables, we include a set of controls in several levels: individual, organizational and environmental (sector and economic context).

First, age (AGE) of the small-business manager has been associated with differences in growth (Davidsson, 1989; Schøtt \& Bager, 2004). Human capital has been related to an entrepreneur's growth orientation (Autio \& Acs, 2007), as education (HIGHEDUC) is a key aspect of the entrepreneur's human capital (Bosma, Praag, Thurik, \& Wit, 2004). Entrepreneurial experience (represented in this study as prior discontinuation of a business, EXIT) and experience as an informal investor or business angel (BUSANG) have been previously associated with growth intentions (Welter, 2001). The intention to set up a business in the near future (FUTSUP) can also be related to growth expectation for the current firm, as a way to adding value to the existing venture or distributing risks (Rosa \& Scott, 1999). Several authors find that entrepreneurs who are less risk averse are more likely to exhibit ambition to grow the firm (Autio \& Acs, 2009; Cassar, 2007), so risk aversion is another relevant individual factor to consider in the determination of growth ambitions. As 
a proxy for risk attitudes, we can include in our study fear of failure (FEARFAIL), which is a component of a person's attitude toward risk (Minniti, 2009) and has been widely employed in GEM studies to approach risk aversion (Arenius \& Minniti, 2005). Finally, according to Autio and Acs (2007) and Terjesen and Szerb (2008), recent personal acquaintance with an entrepreneur (KNOWENT) is significantly and positively related to business growth.

Table 1

Countries participating in the study, by GCR stages of development

\begin{tabular}{|c|c|c|c|}
\hline Uganda & 1 & Chile & 4 \\
\hline $\begin{array}{l}\text { West Bank \& Gaza } \\
\text { Strip }\end{array}$ & 1 & Croatia & 4 \\
\hline Algeria & 2 & Hungary & 4 \\
\hline Guatemala & 2 & Latvia & 4 \\
\hline Jamaica & 2 & Romania & 4 \\
\hline Lebanon & 2 & Russia & 4 \\
\hline Morocco & 2 & Uruguay & 4 \\
\hline Saudi Arabia & 2 & Belgium & 5 \\
\hline Syria & 2 & Finland & 5 \\
\hline Venezuela & 2 & France & 5 \\
\hline Argentina & 3 & Germany & 5 \\
\hline $\begin{array}{l}\text { Bosnia and } \\
\text { Herzegovina }\end{array}$ & 3 & Greece & 5 \\
\hline Brazil & 3 & Hong Kong & 5 \\
\hline China & 3 & Iceland & 5 \\
\hline Colombia & 3 & Israel & 5 \\
\hline Dominican Republic & 3 & Italy & 5 \\
\hline Ecuador & 3 & Korea, Rep. & 5 \\
\hline Iran & 3 & Netherlands & 5 \\
\hline Jordan & 3 & Norway & 5 \\
\hline Malaysia & 3 & Slovenia & 5 \\
\hline Panama & 3 & Spain & 5 \\
\hline Peru & 3 & Switzerland & 5 \\
\hline Serbia & 3 & United Kingdom & 5 \\
\hline South Africa & 3 & United Arab Emirates & 5 \\
\hline- & & United States & 5 \\
\hline
\end{tabular}

Stage of development following GCR Report 20092010 classification:

1 = Stage 1: factor-driven; 2 = Transition to Stage 2;

3 = Stage 2: efficiency-driven; 4 = Transition to Stage 3;

5 = Stage 3: innovation-driven .
As for the control variable in the organizational level, and given the strong relationship between growth intention and realized growth, we must include a control for firm size, in terms of number of employees (SIZE). Although Gibrat (1931) postulates a statistical independence between firm size and firm growth, subsequent research in firm growth, however, does not generally confirm this independence (e.g., Evans, 1987; Petrunia, 2008), so it may be relevant to include it in our model.

Sectorial characteristics have also been considered, specifically the perception of the level of competition in the sector (COMPET) (Dutta \& Thornhill, 2008). We also include a perception of the technology level of the sector (TECHSECTOR), as participation in technology sectors can create perceptions of major opportunities for innovation and growth (Hansen \& Hill, 1991), thus leading to growth expectations. Finally, the decision to grow a firm cannot be fully understood without observing national conditions (Autio \& Acs, 2010), we therefore include the perception of the difficulty of growing a business given the crisis scenario. ${ }^{3}$ 
Table 2

Variables of the study, descriptions and values

\begin{tabular}{ll}
\hline Variable name & Description and values \\
\hline DEPENDENT VARIABLE & \\
HIGHGROWTHEXP & High-growth expectation, i.e., expects to create +20 new jobs in 5 years $\quad(1=$ yes; $0=$ no $)$
\end{tabular}

\section{INDEPENDENT VARIABLES}

\begin{tabular}{|c|c|}
\hline GENDER & Gender $(1=$ female; $0=$ male $)$ \\
\hline \multicolumn{2}{|l|}{ Control variables: } \\
\hline AGE & Exact age at the time of interview \\
\hline HIGHEDUC & High education level attainment $(1=$ yes; $0=$ no $)$ \\
\hline BUSANG & Informal investor in the last 3 years $(1=$ yes; $0=$ no $)$ \\
\hline FUTSUP & Expects to start-up in the next 3 years $(1=$ yes; $0=$ no $)$ \\
\hline EXIT & Discontinued a business in the past 12 months, including business that continued $(1=$ yes; $0=$ no $)$ \\
\hline FEARFAIL & Fear of failure would prevent you from starting a business $(1=$ yes, $0=$ no $)$ \\
\hline KNOWENT & Knows someone personally who started a business in the past 2 years $(1=$ yes; $0=$ no $)$ \\
\hline SIZE & Size 2009, understood as number of jobs in 2009 \\
\hline TECHSECTOR & Firm operates in a technology sector $(1=$ medium or high-tech; $0=$ low-tech or none $)$ \\
\hline COMPET & Level of competition in the sector $(1=$ high; $0=$ low $/$ none $)$ \\
\hline GROWBUS & Growing a business now compared to one year ago is more difficult $(1=$ yes; $0=$ no $)$ \\
\hline \multicolumn{2}{|c|}{ Organizational variables: } \\
\hline TEAMOWNERS & Team of owners-managers, i.e., more than one $(1=$ yes; $0=$ no $)$ \\
\hline EXPORT & $\begin{array}{l}\text { Export intensity relative to turnover }(0=\text { no export; } 1=1-10 \% ; 2=11.25 \% ; 3=26-50 \% \text {; } \\
4=51-75 \% ; 5=76-90 \% ; 6=\text { over } 90 \%)\end{array}$ \\
\hline INNOVATION & $\begin{array}{l}\text { The firm is high or some innovative based on the (potential) customers' view }(1=\text { all or some; } \\
0=\text { none) }\end{array}$ \\
\hline NEWTECH & $\begin{array}{l}\text { Technology employed in the business is new or very new, i.e., available for less than } 5 \text { years } \\
(1=\text { yes; } 0=\text { no). }\end{array}$ \\
\hline
\end{tabular}

\section{Analysis and results}

Given the dichotomous nature of our dependent variable, we perform hierarchical binomial logistic regressions (Hair, Black, Babin, Anderson, \& Tatham, 2006; DeMaris, 2004) in two steps, in order to determine whether the addition of hypothesized variables improved the fit of our data.

In assessing the overall adequacy of the model and the significance of the individual variables, we used the instructions of DeMaris
(2004). First, we assessed the goodness-of-fit of the models using the Model Chi-square test. We further report the Nagelkerke $\mathrm{R}^{2}$ and the Cox and Snell $\mathrm{R}^{2}$, which indicates the variance explained by our models. We also display the overall rate of correct classification of every model in every step. The observation of these different tests allows us to determine the goodness-of-fit of the equations predicted.

First, we test the direct effect of gender (Table 3). Our results reveal that gender is negatively related to entrepreneurs' propensity 
to have high-growth expectation for their firms $(\operatorname{Exp}(B)=0.536 ; p<0.001)$, so that men are almost twice as likely as women to have high aspirations for the future growth of their firms. This allows us to confirm Hypothesis 1.

Second, and to observe possible differences by gender in the effect of the strategic organizational factors on high-growth expectation, we run separate analyses for female and male samples (Table 4). As our objective is to observe possible differences in the factors affecting high-growth expectation between both groups, and following the recommendation given by Hoetker (2007) about the non-use of interaction terms in logistic regressions to compare groups, the segmented analysis we have performed is appropriate to our research objectives. The results of the separate analyses for men and women (Table 4) show that the factors influencing high-growth expectation are not the same for women and men entrepreneurs. First, women provide fewer significant explanatory variables than men, if we consider both control and hypothesized variables. Second, and more importantly, the configuration of the significant organizational variables predicted is different for men and women. For women entrepreneurs, however, the variable referring to innovation level has no significant effect on the probability of having high-growth expectation for the firm. Therefore, we can confirm H2 to H5 (both a/b), except for H4b. 


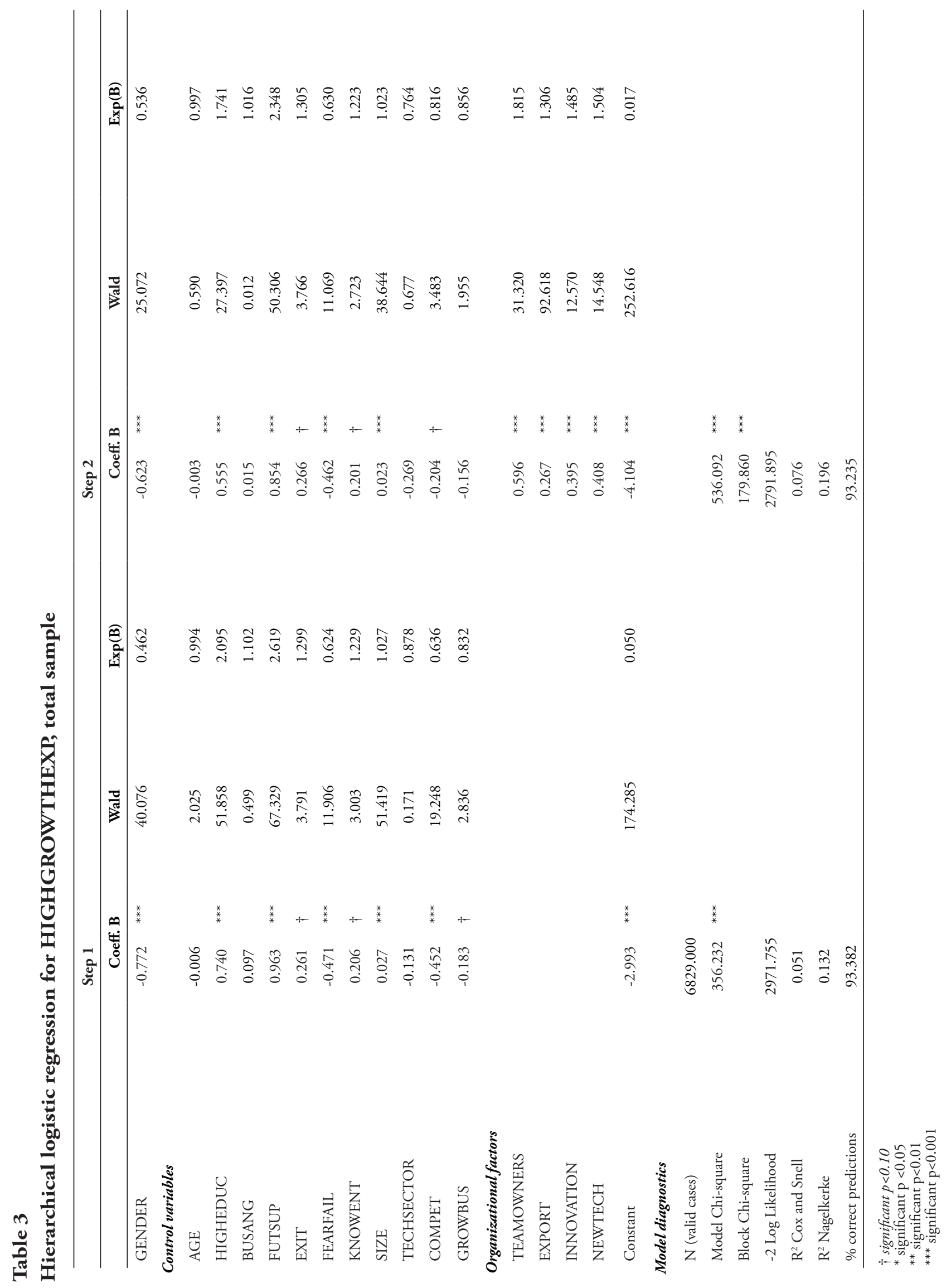




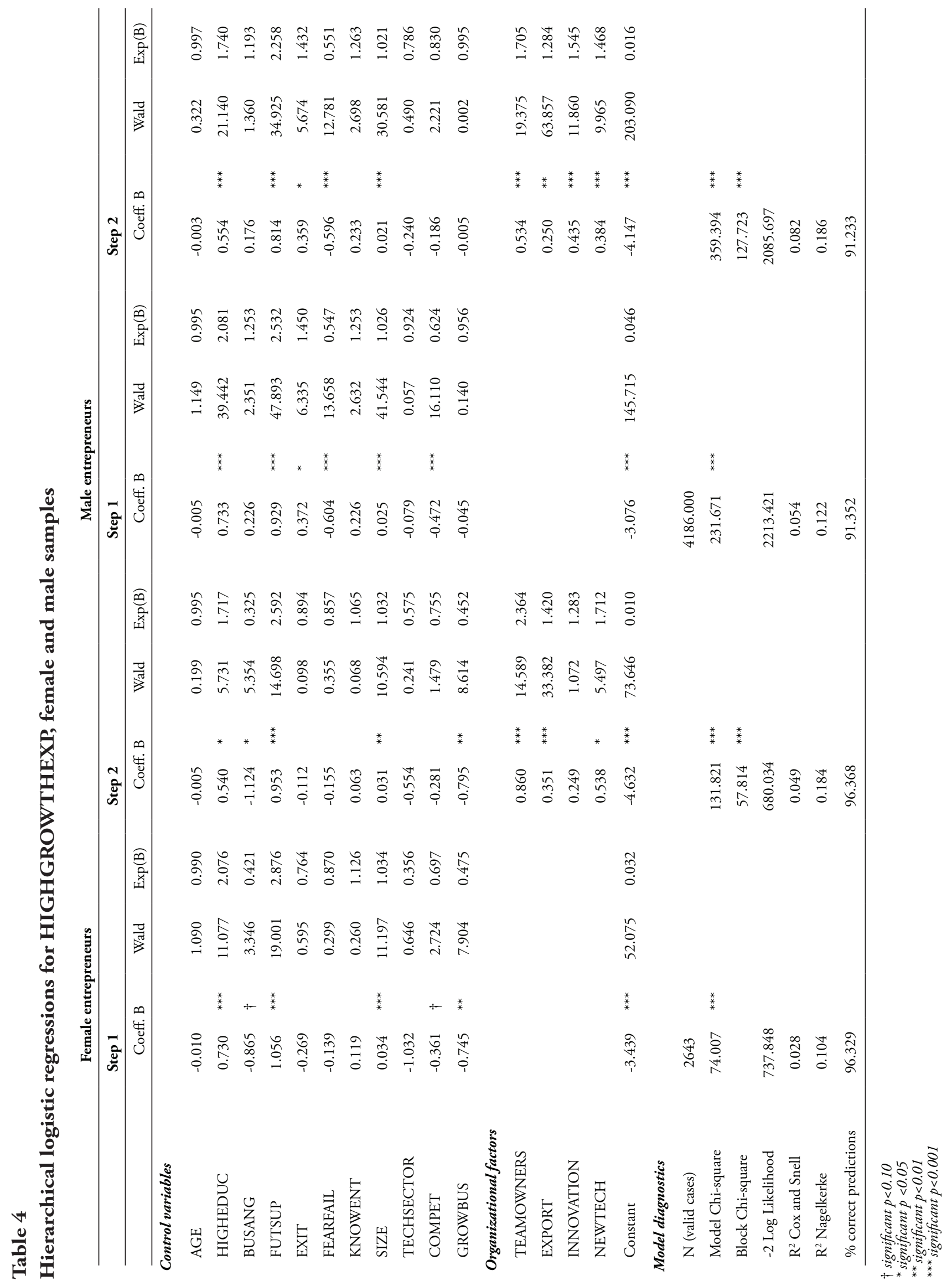




\section{Discussion and conclusions}

Among the numerous factors that can influence the future growth of a firm, the owner's expectation seems to be crucial, given its role as chief contributor to the realized growth of the venture. It is thus relevant to study the factors affecting growth expectation, in order to advance knowledge about the drivers of new ventures' high-growth (Capelleras et al., 2016).

Our results confirm the relevance of organizational variables in predicting high-growth aspirations, in correspondence with research on firm growth, conducted primarily on firm variables (Dutta \& Thornhill, 2008). As expected, the close connection between growth intentions and realized firm growth (Baum \& Locke, 2004; Davidsson, 1989; Delmar \& Wiklund, 2008) permits the correct applicability of RBV in explaining high-growth expectations in new ventures.

From a practical point of view, this implies that strategic decisions such as internationalization, technologies and innovation must be developed by the entrepreneur in order to facilitate a preference for high-growth, and thus guarantee the subsequent survival and growth of the business. Supporting economic policies should take into account these ideas, as growth oriented firms contribute to increased social welfare through job creation and tax revenue (Douglas, 2013). This is particularly relevant for the design of policies fostering entrepreneurship, in such a way that national or regional programs to encourage entrepreneurship will be nor economically successful, neither efficient if, after business creation, entrepreneurs do not find infrastructural support in their country to export, to access financial resources, to innovate, or to adopt new technologies.

On the other hand, based on our results we can confirm gender as a strong explanatory variable for growth aspirations, with women having lower levels of expectation for the highgrowth of their ventures, according to previous results (e.g., Autio \& Acs, 2007; Davis \& Shaver, 2012; Morris et al., 2006).

Moreover, in comparing the determinants of high-growth expectation by gender through the segmented analysis performed, we can conclude that the set of significant predictors is not the same for male and female entrepreneurs. These results suggest a moderating effect of gender shaping the configuration of the factors determining an entrepreneur's propensity for high-growth, in line with previous research that points to a moderator effect of gender on the variables affecting firm growth (Collins-Dodd, Gordon, \& Smart, 2004) and growth intentions (Manolova et al., 2012). Regarding our hypothesized variables, there is only one difference in the model for women compared to the male analysis, as the innovation factor yields a significant effect only in the case of men. One possible explanation is that women's growth expectations may be influenced by factors unrelated to innovation, given their greater tendency to develop their entrepreneurial activity in more traditional sectors (Anna, Chandler, Jansen, \& Mero, 2000), generally considered to be less innovative. However, this result may point at recent concerns in the research on differences in innovation by gender, which has showed to date inconclusive results (Pons, Ramos, \& Ramos, 2016). In this line, it has been suggested that innovation is more related to intrinsic variables (as empowerment or self-confidence) for women than for men (Pons et al., 2016), leading to the idea that variables driving innovation could be different for men and women, with necessary future developments based on combinations of personal and contextual factors (Zhou \& Hoever, 2014). This may indicate the necessity to consider interactions between personal, contextual and organizational factors to better understand the effect of firms' level of innovation on high-growth expectation from a gender perspective, and opens directions for future research on growth expectations.

The results for the control variables may also yield insightful ideas for the study of 
high-growth entrepreneurship. Specifically, the variable used as a proxy for habitual entrepreneur emerges as an important intentional factor in explaining the growth expectation for the actual firm. This may open new paths for future research on the influence of serial and portfolio entrepreneurship in firm growth and growth aspiration.

Like any empirical research, our study is not exempt from limitations. First, the broad scope of our sample can be an advantage for generalization, but it may also constitute a shortcoming, given the heterogeneity inherent to our dataset. Davidsson et al. (2006) suggest the use of more homogeneous samples to control the confounding influence of multiple variables. Based on these ideas, we suggest the use of segmented country-samples to extend the present study. Moreover, further research should build on multilevel modeling, in order to be able to get more complete explanations of an entrepreneur's high-growth expectation, by observing the differing impact of relevant individual variables (gender, strategic organizational factors) depending on the context, or to study interaction effects between variables at different levels. Second, our data do not allow us to consider any growth expectation other than the one based on the number of employees. Reviews of prior literature show that different growth measures can be explained by different growth determinants (Shepherd \& Wiklund, 2009), so the reference measure for growth thus has the potential to influence findings. Future studies on growth expectations could base their dependent variable on other measures to contrast our conclusions and extend our results.

In spite of the above limitations, we should highlight the value of this research, which seeks to contribute to the field of entrepreneurship in several ways. First, since the pursuit of growth through an entrepreneurial venture is seen as a fundamental aspect of strategic entrepreneurial behavior (Davidsson, Delmar, \& Wiklund, 2006b), better understanding of the factors driving high-growth expectation can help advance knowledge in the area of strategic entrepreneurship. Second, our gender perspective contributes to the women's entrepreneurship literature by responding to research calls for more attention to factors affecting the development of women-owned firms (Bruin, Brush, \& Welter, 2007). Third, Autio and Acs (2007) warn of the lack of research on high-growth entrepreneurship in international contexts, due to the limited availability of appropriate data. The international scope of our GEM sample could contribute to filling this research gap.

\section{Notes}

1 The quality of GEM data is widely recognized by both economists and management researchers (Uhlaner \& Thurik, 2007), and it has been proved through previous independent validation tests (Acs, Desai, \& Klapper, 2008). In recent years, a significantly increasing number of publications using GEM data or referring to GEM approach has been observed (Ruiz Navarro, \& García Montesinos, 2013).

2 For more information about the Global Entrepreneurship Monitor, please, see: www.gemconsortium.org

3 Taking into account that our sample is made up of observations from 49 countries, 2009 can represent a good period to study high-growth expectation with an international scope. Given that the beginning of the global economic crisis is acknowledged in 2008 (Organization for Economic Co-operation and Development [OECD], 2009), the worst negative economic effects of the crisis were in 2009 yet to come in the vast majority of the countries, therefore expectations about growing businesses probably have not suffered so much in that period. This has allowed us to undertake a more homogeneous analysis, not too distorted or biased than it would have been with data from subsequent years. However, it has been necessary to include it with the purpose of control, as the world crisis was already present and vastly spread in 2009 (OECD, 2009).

\section{References}

Acs, Z., Desai, S., \& Klapper, L. (2008). What does entrepreneurship data really show? Small Business Economics, 31(3), 265-281.

Alvarez, S. A., \& Busenitz, L. W. (2001). The entrepreneurship of resource-based theory. Journal of Management, 27(6), 755-775. 
Anna, A. L., Chandler, G. N., Jansen E., \& Mero, N. P. (2000). Women business owners in traditional and non-traditional industries. Journal of Business Venturing, 15(3), 279-303.

Arenius, P., \& Kovalainen, A. (2006). Similarities and differences across the factors associated with women's self-employment preference in the Nordic countries. International Small Business Journal, 24(1), 31-59.

Arenius, P., \& Minitti, M. (2005). Perceptual variables and nascent entrepreneurship. Small Business Economics, 24(3), 233-247.

Autio, E., \& Acs, Z. J. (2007). Individual and country-level determinants of growth aspiration in new ventures. Proceedings of the Babson Conference on Entrepreneurship Research, Madrid, Spain.

Autio, E., \& Acs, Z. J. (2009). Institutional influences on strategic entrepreneurial behaviours [Jena Economic Research Papers, 2009-080]. Friedrich Schiller University, Max Planck Institute of Economics, Jena, Germany. Retrieved from http://zs.thulb.uni-jena.de/receive/jportal_ jparticle_00157363

Autio, E., \& Acs, Z. J. (2010). Intellectual property protection and the formation of entrepreneurial growth aspirations. Strategic Entrepreneurship Journal, 4(3), 234-251.

Autio, E., \& Sapienza, H. J. (2000). Comparing process and born global perspectives in the international growth of technology-based new firms. In P. D. Reynolds, E. Autio, C. G. Brush, W. D. Bygrave, S. Manigart, H. J. Sapienza, K. G. Shaver (Eds.), Frontiers of Entrepreneurship Research (pp. 413-424). Babson Park, MA: Babson College.

Autio, E., Sapienza, H. J., \& Almeida, J. G. (2000). Effects of age at entry, knowledge intensity, and imitability on international growth. Academy of Management Journal, 43(5), 909-924.
Barbero, J. L., Casillas, J. C., \& Feldman, H. D. (2011). Managerial capabilities and paths to growth as determinants of high-growth small and medium-sized enterprises. International Small Business Journal, 29(6), 671-694.

Barney, J. B. (1991). Firm resources and sustained competitive advantage. Journal of Management, 17(1), 99-120.

Barringer, B. R., Jones, F. F., \& Neubaum, D. O. (2005). A quantitative content analysis of the characteristics of rapid-growth firms and their founders. Journal of Business Venturing, 20(1), 663-687.

Baum, J. R., \& Locke, E. A. (2004). The relationship of entrepreneurial traits, skill, and motivation to subsequent venture growth. Journal of Applied Psychology, 89(4), 587-598.

Bosma, N., Praag, M. van, Thurik, R., \& Wit, G. (2004). The value of human and social capital investments for the business performance of startups. Small Business Economics, 23(3), 227236.

Bruin, A., Brush, C. G., \& Welter, F. (2007). Advancing a framework for coherent research on women's entrepreneurship. Entrepreneurship Theory and Practice, 31(3), 323-339.

Brush, C. G., Carter, N. M., Gatewood, E., Greene, P. G., \& Hart, M. (2004). Clearing the hurdles: Women building high-growth businesses. Upper Saddle River, NJ: Pearson Education.

Bruton, G. D., \& Rubanik, Y. (2002). Resources of the firm, Russian high-technology startups and firm growth. Journal of Business Venturing, 17(6), 553-576.

Capelleras, J. L., Contín-Pilart, I., LarrazaKintana, M., \& Martin-Sanchez, V. (2016). Unemployment and growth aspirations: The moderating role of education. Strategic Change, 25(2), 171-185. 
Cassar, G. (2006). Entrepreneur opportunity costs and intended venture growth. Journal of Business Venturing, 21(5), 610-632.

Cassar, G. (2007). Money, money, money? A longitudinal investigation of entrepreneur career reasons, growth preferences and achieved growth. Entrepreneurship and Regional Development, 19(1), 89-107.

Castaño, M. S., Méndez, M. T., \& Galindo, M. Á. (2016). Innovation, internationalization and business-growth expectations among entrepreneurs in the services sector. Journal of Business Research, 69(5), 1690-1695.

Chaganti, R. (1986). Management in womenowned enterprises. Journal of Small Business Management, 24(4), 18-29.

Cho, H. J., \& Pucik, V. (2005). Relationship between innovativeness, quality, growth, profitability, and market value. Strategic Management Journal, 26(6), 555-575.

Cliff, J. E. (1998). Does one size fit all? Exploring the relationship between attitudes towards growth, gender, and business size. Journal of Business Venturing, 13(6), 523-542.

Coad, A., \& Tamvada, J. P. (2012). Firm growth and barriers to growth among small firms in India. Small Business Economics, 39(2), 383-400.

Collins-Dodd, C., Gordon, I. M., \& Smart, C. (2004). Further evidence on the role of gender in financial performance. Journal of Small Business Management, 42(4), 395-417.

Cooper, A. C., Gimeno-Gascon, F., \& Woo, C. Y. (1994). Initial human and financial capital as predictors of new venture performance. Journal of Business Venturing, 9(5), 371-395.

Cowling, M., \& Taylor, M. (2001). Entrepreneurial women and men: Two different species? Small Business Economics, 16(3), 167-175.
Davidsson, P. (1989). Entrepreneurship - and after? A study of growth willingness in small firms. Journal of Business Venturing, 4(3), 211-226.

Davidsson, P., Achtenhagen, L., \& Naldi, L. (2006a). What do we know about small firm growth? In S. C. Parker (Ed.), The Lyfe Cycle of Entrepreneurial Ventures (pp. 361398, International Handbook Series on Entrepreneurship, Vol. 3). New York, NY: Springer.

Davidsson, P., Delmar, F., \& Wiklund, J. (2006b). Entrepreneurship as growth; Growth as entrepreneurship. In P. Davidsson, F. Delmar, \& J. Wiklund (Eds.), Entrepreneurship and the Growth of Firms (pp. 21-38). Cheltenham, UK: Edward Elgar Publishing.

Davis, A. E., \& Shaver, K. G. (2012). Understanding gendered variations in business growth intentions across the life course. Entrepreneurship Theory and Practice, 36(3), 495-512.

De Clercq, D. (2005). Firm internationalization by nascent, new and established ventures. In $S$. Zahra et al. (Eds.), Frontiers in Entrepreneurship Research (Chap. 17). Babson Park, MA: Babson College.

Delmar, F.; \& Wiklund, J. (2008). The effect of small business managers' growth motivation on firm growth: A longitudinal study. Entrepreneurship Theory and Practice, 32(3), 437-457.

DeMaris, A. (2004). Regression with social data: Modeling continuous and limited response variables. Hoboken, NJ: Wiley.

Douglas, E. J. (2013). Reconstructing entrepreneurial intentions to identify predisposition for growth. Journal of Business Venturing, 28(5), 633-651.

Dutta, D. K., \& Thornhill, S. (2008). The evolution of growth intentions: Towards a cognition-based model. Journal of Business Venturing, 23(3), 307-332. 
Estrin, S., \& Mickiewicz, T. (2011). Institutions and female entrepreneurship. Small Business Economics, 37(4), 397-415.

European Commision (2014). Annual Report on European SMEs 2013/2014: A Partial and Fragile Recovery. Retrieved from: http://ec.europa.eu/ enterprise/policies/sme/facts-figures-analysis/ performance-review/index_en.htm

Evans, D. S. (1987). Tests of alternative theories of firm growth. Journal of Political Economy, 95(4), 657-674.

Freel, M. S., \& Robson, P. J. (2004). Small firm innovation, growth and performance: Evidence from Scotland and Northern England. International Small Business Journal, 22(6), 561-575.

Gabrielsson, M., Kirpalani, V. H. M., Dimitratos, P., Solberg, C. A., \& Zucchella, A. (2008). Born global: Propositions to help advance the theory. International Business Review, 17(4), 385-401.

Geoffee, R., \& Scase, R. (1983). Business ownership and women's subordination: A preliminary study of female proprietors. The Sociology Review, 33(4), 625-648.

Gibrat, R. (1931). Les inégalités économiques, applications: Aux inégalités des richesses, à la concentration des entreprises, aux populations des villes, aux statistiques des familles, etc.: Dine Loi nouvelle: La Loi de L'effet Proportionnel. Paris, FR: Sirey.

Gilbert, B. A., McDougall, P. P., \& Audretsch, D. B. (2006). New venture growth: A review and extension. Journal of Management, 32(6), 926-950.

Gundry, L. K., \& Welsch, H. P. (2001). The ambitious entrepreneur: High growth strategies of women-owned enterprises. Journal of Business Venturing, 16(5), 453-470.
Hair, J. F., Black, W. C., Babin, B., Anderson, R. E., \& Tatham, R. L. (2006). Multivariate data analysis. Upple Saddle River, NJ: Prentice Hall.

Hambrick, D. C., \& Mason, P. A. (1984). Upper echelons: The organization as a reflection of its top managers. Academy of Management Review, 9(2), 193-206.

Hansen, G. S., \& Hill, C. W. (1991). Are institutional investors myopic? A time-series study of four technology-driven industries. Strategic Management Journal, 12(1), 1-16.

Heinonen, J., Pukkinen, T., \& Nummela, N. (2004). To grow or not to grow? An analysis of internationally growth-oriented Finnish SMEs. Proceedings of the EIBA Annual Conference, Slovenia, 30.

Hessels, J., \& Stel, A. van (2011). Entrepreneurship, export orientation, and economic growth. Small Business Economics, 37(2), 255-268.

Hoetker, G. (2007). The use of logit and probit models in strategic management research: Critical issues. Strategic Management Journal, 28(4), 331-343.

Kazanjian, R. \& Rao, H. (1999). Research note: The creation of capabilities in new ventures - A longitudinal study. Organization Studies, 2O(1), 125-142.

Kleinschmidt, E. J., \& Cooper, R. G. (1991). The impact of product innovativeness on performance. Journal of Product Innovation Management, 8(4), 240-251.

Kolvereid, L. (1992). Growth aspirations among Norwegian entrepreneurs. Journal of Business Venturing, 7(3), 209-222.

Kozlowski, S. W., \& Bell, B. S. (2003). Work groups and teams in organizations. Handbook of Psychology, 2(14), 333-375. 
Lichtenstein, B. (2000). Self-organized transitions: A pattern amid the chaos of transformative change. Academy of Management Executive, 14(4), 128-141.

Lu, J. W., \& Beamish, P. W. (2001). The internationalization and performance of SMEs. Strategic Management Journal, 22(6-7), 565-586.

Manolova, T. S., Brush, C. G., Edelman, L. F., \& Shaver, K. G. (2012). One size does not fit all: Entrepreneurial expectancies and growth intentions of U.S. women and men nascent entrepreneurs. Entrepreneurship and Regional Development, 24(1-2), 7-27.

Manolova, T. S., Carter, N. M., Manev, I. M., \& Gyoshev, B. S. (2007). The differential effect of men and women entrepreneurs human capital and networking on growth expectancies in Bulgaria. Entrepreneurship Theory and Practice, 31(3), $407-$ 426.

McEvily, S. K., Eisenhardt, K. M., \& Prescott, J. E. (2004). The global acquisition, leverage, and protection of technological competencies. Strategic Management Journal, 25(8-9), 713-722.

Menzies, T., Diochon, M., \& Gasse, Y. (2004). Examining venture-related myths concerning women entrepreneurs. Journal of Developmental Entrepreneurship, 9(2), 89-97.

Miller, T., \& Triana, M. C. (2009). Demographic diversity in the boardroom: Mediators of the board diversity-firm performance relationship. Journal of Management Studies, 46(5), 755-786.

Minniti, M. (2009). Gender issues in entrepreneurship. Foundations and Trends in Entrepreneurhip, 5(7-8), 497-621.

Mitra, R. (2002). The growth pattern of womenrun enterprises: An empirical study in India. Journal of Develop-mental Entrepreneurship, 7(2), 217-237.
Montiel Campos, H., Solé Parellada, F., \& Palma, Y. (2012). Mapping the intelectual structure of entrepreneurship research: Revisiting the invisible college. Review of Business Management - Revista Brasileira de Gestão de Negócios, 14(42), 41-58.

Morris, M. H., Miyasaki, N. N., Watters, C. E., \& Coombes, S. (2006). The dilemma of growth: Understanding venture size choices of women entrepreneurs. Journal of Small Business Management, 44(2), 221-224.

O’Regan, N., Ghobadian, A., \& Gallear, D. N. (2006). In search of the drivers of high growth in manufacturing SMEs. Technovation, 26(1), 30-41.

Organisation for Economic Co-operation and Development (2009). The impact of the global crisis on SME and entrepreneurship financing and policy responses. Retrieved from http://www.oecd.org/cfe/smes/theimpacto $\mathrm{ftheglobalcrisisonsmeandentrepreneurshipfinan}$ cingandpolicyresponses.htm

Oviatt, B. M., \& McDougall, P. P. (1994). Toward a theory of international new ventures. Journal of International Business Studies, 25(1), 45-64.

Pagano, P., \& Schivardi, F. (2003). Firm size distribution and growth. Scandinavian Journal of Economics, 105(2), 255-274.

Penrose, E. (1959). The Theory of the growth of the firm. John Wiley: Nueva York.

Petrunia, R. (2008). Does Gibrat's Law hold? Evidence from Canadian retail and manufacturing firms. Small Business Economics, 30(2), 201-214.

Pons, F. J., Ramos, J., \& Ramos, A. (2016). Antecedent variables of innovation behaviors in organizations: Differences between men and women. Revue Européenne de Psychologie Appliquée, 66(3), 117-126.

Reynolds, P., Bosma, N., Autio, E., Hunt, S., De Bono, N., Servais, I., ... Chin, N. (2005). Global 
entrepreneurship monitor: Data collection design and implementation 1998-2003. Small Business Economics, 24(3), 205-231.

Reynolds, P., Bygrave, B., \& Autio, E. (2003). GEM 2003 Executive Report. Babson Park, MA: Babson College.

Rosa, P., Carter, S., \& Hamilton, D. (1996). Gender as a determinant of small business performance: Insights from a British study. Small Business Economics, 8(4), 463-478.

Rosa, P., \& Scott, M. (1999). Entrepreneurial diversification, business-cluster formation, and growth. Environment and Planning C: Government and Policy, 17(5), 527-554.

Ruiz Navarro, J., \& García Montesinos, C. (2013). The entrepreneurship and the NorthSouth European convergence: Evidences from the Global Entrepreneurship Monitor. Revista de Economia Mundial, 35, 21-45.

Schøtt, T., \& Bager, T. (2004). Growth expectations by entrepreneurs in nascent firms, baby businesses and mature firms. In T. Bager, \& M. Hancock (Eds.), The growth of Danish firms (Part 2 of the Global Entrepreneurship Monitor) (pp. 219-230). Copenhagen, DK: Børsens Forlag.

Schwab, K. (2009). Global Competitiveness Report 2009-2010. Geneva, SW: World Economic Forum. Retrieved from https://www. weforum.org/reports/global-competitivenessreport-2009-2010/

Shepherd, D., \& Wiklund, J. (2009). Are we comparing apples with apples or apples with oranges? Appropriateness of knowledge accumulation across growth studies. Entrepreneurship Theory and Practice, 33(1), 105123.

Stam, E. (2010) Growth beyond Gibrat: Firm growth processes and strategies. Small Business Economics, 35(2), 1-7.
Starr, J., \& Yudkin, M. (1996). Women entrepreneurs: A review of current research. Wellesley, MA: Center for Research on Women.

Stenholm, P. (2011). Innovative behavior as a moderator of growth intentions. Journal of Small Business Management, 49(2), 233-251.

Terjesen, S., \& Szerb, L. (2008). Dice thrown from the beginning? An empirical investigation of firm level growth expectations. Estudios de Economía, 35(2), 153-178.

Thornhill, S. (2006). Knowledge, innovation and firm performance in high and low-technology regimes. Journal of Business Venturing, 21(5), 687-703.

Tominc, P., \& Rebernik, M. (2007). Growth aspirations and cultural support for entrepreneurship: A comparison of post-socialist countries. Small Business Economics, 28(2), 239255.

Uhlaner, L., \& Thurik, R. (2007). Postmaterialism influencing total entrepreneurial activity across nations. Journal of Evolutionary Economics, 17(2), 161-185.

United States International Trade Commission. (2010). Small and Medium Sized Enterprises: Overview of Participation in U.S. Exports (Investigation No. 332-508). Washington, DC: USITC Publications. Retrieved from https:// www.usitc.gov/publications/332/pub4125.pdf

Welter, F. (2001). Who wants to grow? Growth intentions and growth profiles of (nascent) entrepreneurs in Germany. Proceedings of the Annual Entrepreneurship Research Conference, Jönköping, Sweden, 21.

Wiklund, J., \& Shepherd, D. (2003). Aspiring for, and achieving growth: The moderating role of resources and opportunities. Journal of Management Studies, 40(8), 1911-1941. 
Wiklund, J., Patzelt, H., \& Shepherd, D. (2009). Building an integrative model of small business growth. Small Business Economics, 32(4), 351-374.

Zheng, C., \& Khavul, S. (2005). Capability development, learning and growth in international entrepreneurial firms: Evidence from China. In: D. A. Shepherd, \& J. A. Katz (Eds.), International entrepreneurship (pp. 273-296, Advances in Entrepreneurship, Firm Emergence and Growth, Vol. 8). Bingley, UK: Emerald Group Publishing.

Zhou, J., \& Hoever, I. J. (2014). Research on workplace creativity: A review and redirection. Annual Review of Organizational Psychology and Organizational Behavior, 1, 333-359.

\section{Supporting Agencies:}

The authors gratefully acknowledge the financial support received from the Spanish Ministry of Economy and Competitiveness [ECO2012-36053], the Andalusian Government [P12-SEJ-2396] and the European Regional Development Fund (ERDF).

\section{About the authors:}

1. Matilde Ruiz Arroyo, PhD in Business Administration and Management, Associate Professor University of Granada. E-mail: matilderuiz@ugr.es.

2. María del Mar Fuentes Fuentes, PhD in Economic and Business Sciences, Full Professor University of Granada. E-mail: mfuentes@ugr.es.

3. Jenny María Ruiz Jiménez, PhD in Economic and Business Sciences, Assistant Professor University of Granada.E-mail: jmruizj@ugr.es.

\section{Contribution of each author:}

\begin{tabular}{|c|c|c|c|}
\hline Contribution & $\begin{array}{c}\text { Matilde Ruiz } \\
\text { Arroyo }\end{array}$ & $\begin{array}{c}\text { María del Mar } \\
\text { Fuentes Fuentes }\end{array}$ & $\begin{array}{c}\text { Jenny María Ruiz } \\
\text { Jiménez }\end{array}$ \\
\hline Definition of research problem & $\sqrt{ }$ & $\sqrt{ }$ & \\
\hline Development of hypotheses or research questions (empirical studies) & $\sqrt{ }$ & $\sqrt{ }$ & $\sqrt{ }$ \\
\hline 3. Development of theoretical propositions (theoretical Work) & $\sqrt{ }$ & $\sqrt{ }$ & \\
\hline 4. Theoretical foundation/ Literature review & $\sqrt{ }$ & $\sqrt{ }$ & $\sqrt{ }$ \\
\hline 5. Definition of methodological procedures & $\sqrt{ }$ & & \\
\hline 6. Data collection & $\sqrt{ }$ & & \\
\hline 7. Statistical analysis & $\sqrt{ }$ & & \\
\hline 8. Analysis and interpretation of data & $\sqrt{ }$ & $\sqrt{ }$ & $\sqrt{ }$ \\
\hline 9. Critical revision of the manuscript & $\sqrt{ }$ & $\sqrt{ }$ & $\sqrt{ }$ \\
\hline 10. Manuscript Writing & $\sqrt{ }$ & $\sqrt{ }$ & $\sqrt{ }$ \\
\hline 11. Other (please specify which) & & & \\
\hline
\end{tabular}

